\title{
FINANCIAL, ECONOMIC AND ADMINISTRATIVE METHODS OF PUBLIC ADMINISTRATION THAT PROVIDE THE RIGHT FOR HEALTHCARE TO PERSONS WITH DISABILITIES
}

\begin{abstract}
Ensuring the right of persons with disabilities for healthcare is one of the main tasks of state policy in the field of healthcare. The implementation of the tasks of the state policy on ensuring the right for healthcare for persons with disabilities is carried out by means of financial, economic and administrative methods of public administration. Along with the administrative methods of public administration of the right for healthcare for persons with disabilities, another group of methods that ensure the right for healthcare for persons with disabilities is important - the adoption of programs for economic development of healthcare, adoption and financing of rehabilitation programs for persons with disabilities, provision of medical measures of separate state programs and complex measures based on program principles, realization of pilot projects on change of the mechanism of financial maintenance of operative treatment with transplantation of organs and other anatomic materials, etc. Therefore, we will pay attention to the problems of application of financial, economic and administrative methods of public administration of the right of persons with disabilities for healthcare.
\end{abstract}

Keywords: healthcare, person with disability, economic methods of public administration, administrative methods of public administration, disability.

\section{INTRODUCTION}

The main purpose of economic methods of public administration in ensuring the right for healthcare of persons with disabilities is the creation of economic conditions that arouse interest in performing certain work, increasing productivity and, consequently, providing financial support. When applying economic methods of management, the subject of management achieves the proper behaviour of the managed by influencing their material interests. For this purpose, the prospects of material advantages and the threat of material

\footnotetext{
1 Viktoriya Chorna, Doctor of Law, Associate Professor, Professor of the Department of Constitutional, Administrative and Criminal Law of Kyiv National Economic University named after Vadym Hetman (corresponding author); e-mail: demidenkov@ukr.net. ORCID: 0000-0002$-6072-0283$.

${ }^{2}$ Lyudmyla Kozhura, Doctor of Law, Associate Professor, Professor of the Department of Theory and History of Law of Kyiv National Economic University named after Vadym Hetman; e-mail: lepel@ukr.net. ORCID: 0000-0003-4100-9530.
} 
sanctions can be used to the same extent (Kolpakov, 1999). These methods should be used to regulate the activities of so-called non-profit institutions, taking into account, for example, how rationally they spend their own material resources received from the provision of paid services, lease of state property and real estate (Ihnatchenko, 2009).

\section{LITERATURE REVIEW}

Some issues of the study of economic and administrative methods of public administration, providing persons with disabilities with the right for healthcare were the subject of the research of administrators: V. Averyanov, S. Alekseyeva, N. Armash, D. Bakhrakh, Yu. Bytyak, O. Dzhafarova, Ye. Dodin, R. Kalyuzhnyi, S. Kivalov, L. Koval, T. Kolomoyets, V. Kolpakov, A. Komzyuk, L. Kozhura, O. Kuzmenko, V. Kurylo, I. Lychenko, D. Lukyantsya, P. Lyutikova, T. Matselyk, R. Melnyk, O. Mykolenko, D. Priymachenko, A. Sotska, S. Tykhomyrov, V. Chorna, V. Shkarupa and others. The following scientists devoted their works to the issues of social protection of persons with disabilities, realization of the rights of persons with disabilities: M. Avramenko, V. Azin, L. Bayda, S. Bogdanova, N. Boretska, S. Burov, Y. Grybalskyi, Ye. Libanova, L. Koleshnya, M. Kravchenko, O. Krasyukova-Enns, O. Makarova, K. Mishchenko, Yu. Nayda, V. Skurativskyi, V. Sushkevych and others.

An effective way to ensure the right for healthcare for persons with disabilities is to use financial, economic and administrative methods of public administration.

The first part of the article examines economic methods of public administration that provide people with disabilities with the right for healthcare. The second part reveals the concepts and types of administrative methods of public administration that provide persons with disabilities with the right for healthcare. The conclusions suggest the ways to improve legal understanding and types of financial, economic and administrative methods of public administration that provide persons with disabilities with the right for healthcare.

\section{RESULTS AND DISCUSSION}

It should be noted that in the process of administrative and later medical reforms, the methods of regulatory influence (indirect management), among which the leading place is occupied by economic management methods, are of considerable importance. Their application ensures the meeting of financial and material interests of management objects through the activities of its subjects, which create favourable conditions for achieving the goals and objectives of management, for example, local governments within their competence may finance local programs of development and support of public health facilities, including the renewal of material and technical base, overhaul, reconstruction, increase of salaries of medical workers ("local incentive programs"), as well as local programs of medical services, local public healthcare programs and other programs in the field of healthcare. (Law of Ukraine, 2018).

Economic methods may include material incentives through a system of specially created funds that accumulate and distribute budget funds for healthcare together with private capital; identify priority areas for financing and promoting the development of medical care for persons with disabilities; provide funding for training and retraining programs for specialists who provide medical care for people with disabilities; to redistribute funds from state, local and other sources for treatment of certain types of 
diseases; establish a system of grants and trust funds for application of various mechanisms for controlling the use of resources etc.

Thus, economic methods are manifested in the creation of such conditions for development of subordinated objects, under which they, influenced by certain material and financial incentives, can independently choose one or another behaviour. However, this choice is still based on the traditional "residual" principle of public funding for healthcare, which, unfortunately, cannot be overcome in the near future. Economic methods can be applied on a relatively limited scale. Therefore, we should look for new methods of comprehensive investment in healthcare, including sources of funding healthcare for people with disabilities through the use of budgets at various levels, attracting charitable contributions (development of philanthropy and sponsorship), expanding the scope of business in the studied sphere of administration.

It should be noted that the application of economic methods of public administration of the right for healthcare for persons with disabilities requires the search of specific performance indicators of subordinated objects, as well as special criteria for assessing its effectiveness.

Thus, in the state budget of Ukraine for 2018, the expenditures according to the functional classification of expenditures and budget lending for healthcare and social protection, including for persons with disabilities, were as follows:

- measures for rehabilitation of patients with cerebral palsy - 14,154,000.00 UAH;

- implementation of a pilot project to change the mechanism of financial support of surgical treatment of organ transplantation and other anatomical materials 112,015,300.00 UAH;

- provision of primary medical care to the population -8,054,517,600.00 UAH;

- subvention from the state budget to local budgets for the purchase of consumables for healthcare facilities and drugs for inhalation anaesthesia - 18,972,600.00 UAH;

- subvention from the state budget to local budgets to reimburse the cost of medicines for treatment of certain diseases - 1,000,000,000.00 UAH;

- specialized prosthetic, orthopaedic and medical rehabilitation care for the disabled in the clinic of the Research Institute of Prosthetics, Prosthetic Construction and Rehabilitation - 23,384,300.00 UAH;

- measures for social protection of children, families, women and other most vulnerable categories of population - 100,789,900.00 UAH;

- provision of one-time financial assistance to family members of persons who perished (died) during the participation in the anti-terrorist operation, and to the persons who received a disability group during the participation in the specified operation - 48,748,700.00 UAH;

- one-time financial assistance to a family member of a volunteer who died while providing volunteer assistance in the anti-terrorist operation zone, and to a volunteer who became a person with disability due to an injury received during the assistance $-815,700.00 \mathrm{UAH}$.

Instead, in accordance with the Law of Ukraine "On State Budget - 2019", the following expenditures were planned for the field of healthcare to ensure directly the implementation of the right for healthcare for persons with disabilities:

- subvention from the state budget to local budgets for purchase of medicines and medical devices to provide emergency medical care - 137,992.30 UAH; 
- subvention from the state budget to local budgets for purchase of angiographic equipment - 150,000.00 UAH;

- subvention from the state budget to local budgets to reimburse the cost of medicines for treatment of certain diseases - 250,000.00 UAH;

- subvention from the state budget to the district budget of Valky district of Kharkiv region for the purchase of a computer tomograph for the municipal healthcare institution "Valky Central District Hospital" - 12,500.00 UAH;

- advanced training of employees of the social protection system - 644.10 UAH;

- specialized prosthetic, orthopaedic and medical rehabilitation care for persons with disabilities in the clinic of the Research Institute of Prosthetics, Prosthetic Construction and Rehabilitation - 26,768.90 UAH;

- measures for social protection of children, families, women and other most vulnerable categories of population - 95,570.30 UAH;

- rehabilitation and recreation of children in need of special attention and support in children's health camps ICC "Artek" and CC "Young Guard" - 217,192.10 UAH;

- sanatorium treatment of war veterans, persons covered by the law of Ukraine "On status of war veterans, guarantees of their social protection", "On victims of Nazi persecution" and persons with disabilities - 193,165.90 UAH;

- measures for psychological rehabilitation, social and professional adaptation, provision of sanatorium treatment to victims of the Revolution of Dignity, participants of the anti-terrorist operation and persons who carried out measures to ensure national security and defence, repel and deter armed aggression in Donetsk and Lugansk regions - 110,905.60 UAH;

- financial support of public associations of persons with disabilities having the status of all-Ukrainian associations - 89,362.40 UAH, including financial support of the National Assembly of Persons with Disabilities of Ukraine, enterprises and organizations of non-productive sphere of the Ukrainian Society of the Blind and the Ukrainian Society of the Deaf and the Union of Organizations of Persons with disability of Ukraine - 76,025.90 UAH;

- measures for social, labour and professional rehabilitation of persons with disabilities - 1,335,591.00 UAH;

- ensuring the activities of the Fund for Social Protection of the Disabled - 85,678.00 $\mathrm{UAH}$;

- rehabilitation of children with disabilities due to cerebral palsy - 130,022.60 UAH;

- subvention from the state budget to local budgets for payment of monetary compensation for housing for families of persons specified in the clauses 5-8 of paragraph 1 of Article 10 of the Law of Ukraine "On status of war veterans, guarantees of their social protection" for persons with disabilities of the groups I-II, which occurred as a result of injuries, contusions, traumas or illnesses received during direct participation in the anti-terrorist operation, ensuring its implementation, taking measures to ensure national security and defence, repulse and deter armed aggression of the Russian Federation in Donetsk and Lugansk regions, their implementation, defined by paragraphs 11-14 of the second part of Article 7 of the Law of Ukraine "On status of war veterans, guarantees of their social protection", and which require improvement of living conditions - 305 145.3 UAH (Law of Ukraine, 2019); 
- subvention from the state budget to local budgets for payment of monetary compensation for housing to internally displaced persons who defended the independence, sovereignty and territorial integrity of Ukraine and participated directly in the anti-terrorist operation, ensuring its implementation, being directly in the zones of the anti-terrorist operation, during implementation of measures to ensure national security and defence, repulse and deter the armed aggression of the Russian Federation in Donetsk and Lugansk regions, ensuring their implementation, being directly in the districts and during the implementation of these measures, and recognized as disabled of the III group in accordance with paragraphs 11-14 of the second part of Article 7, or combatants in accordance with paragraphs 19-20 of the first part of Article 6 of the Law of Ukraine "On status of war veterans, guarantees of their social protection" and in need of better living conditions - $25000,00 \mathrm{UAH}$ (Law of Ukraine 2018, Appendix 3).

At the same time, we note that, in accordance with the expenditures of the State Budget of Ukraine planned for the year 2020, the costs of healthcare for persons with disabilities are as follows:

- public health and fight against epidemics $-2,121,032.80 \mathrm{UAH}$;

- creation of a modern clinical base for treatment of cancer at the National Cancer Institute - 700,000 UAH;

- implementation of the state investment project "Improvement of molecular genetic diagnosis of cancer in Ukraine" - 100,000 UAH;

- sanatorium treatment of patients with tuberculosis and children and adolescents with somatic diseases - 573,390.40 UAH;

- specialized prosthetic-orthopaedic and medical-rehabilitation care for persons with disabilities in the clinic of the Research Institute of Prosthetics, Prosthetic Construction and Rehabilitation - 34,500.70 UAH;

- measures for social protection of children, families, women and other most vulnerable categories of population - 66,019.80 UAH;

- annual one-time assistance to war veterans and victims of Nazi persecution and social assistance to persons who have special labour merits to the Motherland 1,382,540.60 UAH;

- social protection for persons affected by Chornobyl accident - 2,570,195.0 UAH (Law of Ukraine, 2019).

It should also be noted that in 2020 a new mechanism was introduced to provide rehabilitation measures for children with disabilities due to cerebral palsy on the principle of "money follows a person", which should ensure targeting, transparency and improve the quality of rehabilitation services. In pursuance of the Law of Ukraine "On State Budget of Ukraine - 2020", which provides for expenditures under the budget program 2507100 "Rehabilitation of children with disabilities due to cerebral palsy" the Cabinet of Ministers of Ukraine adopted a program "On approval of the Procedure for use of funds provided in the state budget for rehabilitation of children with disabilities due to cerebral paralysis in 2019” dd. 27.03.2019 No. 309 (Law of Ukraine, 2019).

The procedure for using the funds provided in the state budget for rehabilitation of children with disabilities due to cerebral palsy in 2020 stipulates that the main administrator of budget funds is the Ministry of Social Policy. Managers of lower level budget funds are: Social Protection Fund for the Disabled - responsible executor of the budget program; 
executive body in the Autonomous Republic of Crimea on issues of social protection of population, structural subdivisions on issues of protection of the population of regions, Kyiv City State Administration; structural subdivisions on social protection of population of district, Kyiv local state administrations, city executive bodies, district councils (in case of their formation) (hereinafter - local bodies) (Ministry of Social Policy of Ukraine, 2020).

Funds are distributed on a vertical basis - initially between regional authorities, which, in turn, distribute budget funds among local authorities in proportion to the number of children in need of rehabilitation, according to their place of residence (stay) and individual rehabilitation programs (Ministry of Social Policy of Ukraine, 2020). It should be noted that on the basis of the appeals of these entities the redistribution of funds allocated for implementation of rehabilitation measures can be made.

These program-targeted economic methods of public administration of the right of persons with disabilities for healthcare are applied to healthcare institutions of any form of ownership and organizational and legal form, providing medical care for persons with disabilities and (or) their rehabilitation on the basis of appropriate license and professional activity of medical (pharmaceutical) workers who have a license to conduct business in medical practice in order to reimburse the cost of rehabilitation measures for children in need of rehabilitation measures.

Thus, the use of funds provided in the state budget for rehabilitation of children with disabilities due to cerebral paralysis by local communities is an effective method of public administration of the right for healthcare of persons with disabilities.

Another effective economic method of public administration of the right for healthcare of persons with disabilities is to develop a mechanism for using funds provided in the state budget by local communities to purchase specially equipped vehicles for transportation of persons and children with disabilities of musculoskeletal system. The application of this method will provide an opportunity to encourage local communities to create transportation services for people with disabilities, especially people in wheelchairs. The implementation of these measures will positively contribute to the removal of barriers in the lives of people with disabilities.

The mechanism of application of this economic method of public administration of the right for healthcare of persons with disabilities is approved in the resolution of the Cabinet of Ministers of Ukraine dd. March 14 ${ }^{\text {th }}, 2018$ No. 189 "Some issues of using funds provided in the state budget for persons and children with disabilities of musculoskeletal system" (Law of Ukraine, 2018). It should be noted that in accordance with the budget program 2507030 "Measures for social, labour and professional rehabilitation of persons with disabilities" 30,000 thousand UAH were provided for the year 2019 in this sphere.

We also note that the economic methods of public administration of the right for healthcare for persons with disabilities, in our opinion, also include: targeted approach to provision of technical and other means of rehabilitation of persons with disabilities; provision of persons with disabilities according to the principle of "money follows a person"; payment of compensation for self-purchased rehabilitation equipment etc.

The next type of public administration that provides people with disabilities with the right for healthcare is administrative one.

Administrative methods of public administration should be understood as a set of methods and tools used in their activities by public administrations in order to influence the behaviour of individuals. An entity that uses the administrative method is an authority that performs administrative functions, including if they are delegated to it. At the same time, 
the object is the behaviour and actions of persons influenced by the subject of power. The use of administrative methods of public administration is aimed at ensuring the right of persons with disabilities for healthcare. Administrative and legal methods are inseparable from the process of exercising executive power, public administration cannot be supplanted by civil law categories of the contractual type. It is also obvious that the methods play a crucial role in ensuring proper legal order, the level of state discipline (Kolpakov, Kuzmenko, 2003).

The administrators Yu.P. Bytyak and V.M. Garashchuk suggest to understand the administrative and legal methods of public administration as the ways and receptions of direct and purposeful influence of executive bodies (their officials) on the basis of the competence assigned to them, within the established limits and the corresponding forms on the bodies subordinated to them, individuals and legal entities (Bytiak, 2001).

Yu. M. Kozlov divides administrative methods of public administration into two groups: non-economic (direct) ones and of economic (indirect) influence (Kozlov, 2003).

A.Ye. Lunyov proposes to apply the methods of public administration into four independent groups: moral and political, economic, organizational, administrative and directive ones (Lunev, 1970).

G.V. Atamanchuk - also divided into four groups: moral and ideological, sociopolitical, economic, administrative one. There are other approaches, when individual, collegial, collective, combined methods, etc. are outlined (Atamanchuk, 2003).

It should be noted that the lack of a single classification of methods of public administration indicates the different purpose of their use, delimitation and grouping of means and methods of influencing the consciousness and behaviour of people in the process of public management as to public administration of any given human right. The same applies to the right of persons with disabilities for healthcare.

The use of public administration methods is always carried out due to meet objective needs, in this case it is about ensuring the right of persons with disabilities for healthcare. That is why the methods used to ensure the right for healthcare of persons with disabilities must be objectively determined, and those that ensure the implementation of international principles on accessibility, equality and freedom of access to quality and timely medical care and a barrier-free environment.

Administrative methods are characterized by relations such as "power - subordination", they most clearly express the administrative nature of the management activities of public administration entities that ensure the right for healthcare of persons with disabilities. The use of administrative methods allows the subject of this activity (for example, the Ministry of Social Policy of Ukraine, the Ministry of Healthcare of Ukraine) to influence the object of activity directly (public relations arising in the process of exercising the right for healthcare of persons with disabilities). However, in case of reorganization, the objects, whom the administrative methods are applied to, may influence the activities of authorized entities, such as public organizations of persons with disabilities, their unions, which are established to ensure equal rights and opportunities for persons with disabilities and their social protection as well as for public control over the observance of rights of persons with disabilities, representation of their interests and elimination of any manifestations of discrimination against persons with disabilities and have the right to enjoy the benefits and preferences provided by law (Law of Ukraine 1991).

According to the method of influence, administrative methods are divided into those that oblige to perform certain actions, and those that authorize to perform certain actions; 
encouraging socially useful actions; prohibiting the commission of any actions (Bandurka, 1998). For example, the Decree of the President of Ukraine "On Measures to Ensure Respect for Rights of Persons with Disabilities" of the Cabinet of Ministers of Ukraine instructed local executive bodies to ensure and to analyse additional measures to intensify the work on implementation of the provisions of the Convention on the Rights of Persons with Disabilities with the involvement of public associations that care for persons with disabilities. Instead, Art. 9 of the Law of Ukraine "On Fundamentals of Social Protection of Persons with Disabilities" authorizes central and local executive bodies, local governments with the participation of public organizations of persons with disabilities, within its powers to develop and coordinate long-term and short-term programs for implementation of public policy regarding persons with disabilities and monitor their implementation (Law of Ukraine 2007, Article 9). And the resolution of the Cabinet of Ministers of Ukraine "On approval of the procedure for granting permission for the right to use tax benefits for enterprises and organizations of public organizations of the disabled" provides for state incentives for enterprises and organizations established by public organizations of the disabled by granting permission for the right to use tax. Legislation, guaranteeing the right for healthcare of persons with disabilities, prohibits discrimination on the grounds of disability.

Thus, the application of administrative methods of public administration of the right of persons with disabilities for healthcare is carried out in order to ensure:

1) free and equal opportunities for persons with disabilities to exercise their right for healthcare;

2) purposefulness of administrative activity of competent subjects of public administration;

3) ensuring the legitimacy of the behaviour of participants in administrative relations;

4) ensuring the interaction of all participants in administrative relations - public administration bodies, public associations, persons with disabilities.

In view of the above, the administrative methods of public amnesty for the right for healthcare of persons with disabilities, in our opinion, should be divided into 4 groups.

The first group is intended to ensure the proper quality of the administrative process, when the governing bodies (officials) adjust their own decisions to the needs of management objects. These are the means, methods and actions associated with preparation and implementation of administrative decisions, their legal consolidation, organization and control over their implementation benefits (Ihnatchenko, 2009).

The second group is designed to ensure the proper functioning of enterprises, organizations and institutions in the field of healthcare, which ensure the exercise of the right for healthcare of persons with disabilities. Their specificity is manifested mainly in the impact on direct activities of these objects, which necessitates the search for effective tools and techniques for a particular system (subsystem) of public administration of the right for healthcare of persons with disabilities. These methods are derived from the methods of the first group, as they specify the content of the latter in relation to the local range of objects and are implemented in all parts of the administrative system of healthcare facilities, especially its basic level - departments and divisions of local administrations or local governments.

Despite the importance of the activities of public administration entities that guarantee the right for healthcare of persons with disabilities, the first and second groups of methods have a coordinating and regulatory impact directly on the activities of public administration 
bodies in the field of healthcare. At the same time, the full achievement of the goals and objectives of the state to guarantee the right for healthcare of persons with disabilities is impossible without introduction of methods of direct (immediate) influence. These methods, which are traditionally called administrative, are characterized by one-sided governmental influence of the subject of management on the object. They are manifested in the issuance of orders, decisions, for non-compliance with which the object of management may be held administratively or disciplinary liable (Dorokhova, Kozyreva, Serhyenko, Shabailov, 1988). As noted in the literature, among the factors that led to the deterioration of the situation in some areas of public administration (including public healthcare) the following should be mentioned: the lack of an optimal combination of centralization and decentralization; underestimation of the administrative-legal method of regulation of public relations, and sometimes its mixing with administration or administrative-command style of management (Bytiak, 2001). We are currently talking about the application of the third and fourth groups of methods of public administration of the right for healthcare of persons with disabilities, which we have identified.

The experience of world development shows that the processes of transformation of public relations in the field of healthcare, including the provision of the right for healthcare of persons with disabilities must be managed, including the use of methods of direct influence. However, we emphasize that the very content of operating with these methods should be changed taking into account the needs of people with disabilities. Their use is appropriate, for example, to eliminate or compensate for the consequences caused by persistent health problems, functioning of the system of maintaining the, mental, social well-being of persons with disabilities, and helping them to achieve social and material independence.

The third group of methods of public administration of the right for healthcare are the methods that have a service nature of ensuring the right for healthcare of persons with disabilities. This is a permit, registration, licensing.

Enterprises and organizations established by public associations of persons with disabilities have the right to obtain a permit for the right to use tax benefits. The subject of this type of permit is a central executive body that implements the state policy in the field of social protection of persons with disabilities, war veterans (Ministry of Social Policy of Ukraine), regional, Kyiv city state administration. The permit can be issued for a quarter, half a year, three quarters, a year.

Permission to enterprises with branches, separate subdivisions (if any) and organizations established by public associations of persons with disabilities is granted provided that they meet the following criteria: 1) the number of persons with disabilities who have their main place of work at enterprises and organizations, makes not less than 50 percent of the average number of full-time employees of the accounting staff during the previous reporting (tax) period; 2) the remuneration fund of persons with disabilities who have the main place of work at enterprises and organizations during the reporting period is not less than 25 percent of the total labour costs that are part of the costs in accordance with the rules of corporate income tax; 3 ) the amount of costs of the enterprise, organization for processing (other types of transformation) of raw materials, components, other purchased goods (services) used for manufacture of goods (services) directly by enterprises, organizations, is not less than 8 percent of the supply price of such manufactured goods (provision of services); 4) the amount of the average monthly salary in the equivalent of full employment of persons with disabilities who have the main place of work at enterprises, organizations, must be not less 
than the legally established amount of the minimum wage; 5) implementation by enterprises, organizations of decisions of the Ministry of Social Policy and regional, Kyiv city state administration (Law of Ukraine, 2007).

In our opinion, the permission for the right to use tax benefits granted to enterprises and organizations established by public organizations of persons with disabilities is an effective means of public administration of the right for healthcare for persons with disabilities for the following reasons:

1) it creates financial preferences and incentives for enterprises and organizations established by public organizations of the disabled to attract persons with disabilities to work;

2) a person with disability who is engaged in labour activity is more mobile, involved in social life, is in contact with the environment and people, which provides not only labour but also physical employment;

3) employment of persons with disabilities is an additional source of income for the latter, in addition to social assistance established by the state. higher income of a socially vulnerable person allows him/her to receive not only free medical care, which unfortunately, today, does not always meet the needs of a person with disabilities, but also to pay for paid medical services that he/she needs due to his/her health and special needs.

The next method of public administration of the right to health of persons with disabilities is registration. The main entity carrying out registration activities is the Ministry of Social Policy of Ukraine and its structural subdivisions.

For example, a person with disability, a child with disability who is registered as an internally displaced person, have the right to receive social services in accordance with the legislation of Ukraine at the place of registration of the actual place of residence of such an internally displaced person. An internally displaced registered person from among persons with disabilities, a child with a disability have the right to be provided with technical and other means of rehabilitation, to receive rehabilitation services in accordance with the legislation at the place of residence. Provision of technical and other means of rehabilitation, provision of rehabilitation services is carried out in the presence of the necessary documents confirming the right for these services and means, and in case of their absence - according to the Centralized Disability Data Bank (for re-applicants) and individual program rehabilitation of a person with disability, a child with disability in the manner prescribed by the Cabinet of Ministers of Ukraine (Law of Ukraine, 2014, art. 7).

Additionally, the Ministry of Social Policy of Ukraine carries out registration activities on: registration of internally displaced persons for the right to obtain registration of employers and data on employment of persons with disabilities; registration of medicines necessary for persons with disabilities; maintaining a register of persons with disabilities.

Carrying out the registration activity of authorized subjects of public administration ensures the right for health protection of persons with disabilities by:

1) providing the opportunity to monitor the number of persons with disabilities and, accordingly, to forecast the necessary quantitative and qualitative indicators of medicines, organization and implementation of rehabilitation measures, etc.;

2) the possibility for different categories of persons with disabilities to receive equal and free expression of the right for healthcare.

The next service for public administration of the right for healthcare for people with disabilities is licensing. 
So, for example, in accordance with the provisions of the resolution of the Cabinet of Ministers of Ukraine "On approval of licensing conditions for business activities for production of medicines, wholesale and retail trade in medicines, import of medicines (except active pharmaceutical ingredients)" a licensee, who carries out activities in the retail sale of medicines, creates the necessary conditions for the accessibility of persons with disabilities and other low-mobility groups to the premises in accordance with state building codes, regulations and standards. In the absence of the necessary conditions for accessibility of persons with disabilities and other low-mobility groups to the premises in accordance with state building codes, rules and standards a license to conduct business in manufacture of medicines, wholesale and retail trade in medicines, import of medicines (except active pharmaceutical ingredients) is not provided.

Thus, through licensing activities, the public administration has the opportunity to regulate the issues of accessibility and unimpeded access to public places for people with disabilities, which will ensure their right for healthcare. In this case, we mean the accessibility and creation of a barrier-free environment for people with disabilities to visit healthcare facilities, including pharmacies, clinics, and other medical facilities, where a person with disability can receive the necessary medical care or medical service.

The fourth group of administrative methods of public administration of the right for healthcare for persons with disabilities are methods that have the managerial nature of ensuring the right for healthcare for persons with disabilities. These, in our opinion, should include: monitoring, accounting, standardization, certification of employees working with persons with disabilities, control, supervision, administrative liability for violations of the rules that ensure the right for healthcare of persons with disabilities.

The main method of public administration of the right for healthcare of persons with disabilities is the method of control. In the most general sense, the concept of "control" means observation, supervision of anything, in order to verify the conformity of certain actions in the field of production, public administration or behaviour of citizens (Krutskykh, 1999). Control is also understood as checking the implementation of decisions or responsibilities imposed by the state and society on enterprises, institutions, organizations, officials and citizens, compliance with legal and social norms, elimination of deviations from specified programs of activities and regulatory requirements (Tsvietkov, 1998).

A wide range of public administration entities monitor the right for healthcare of persons with disabilities. For example, the Ministry of Healthcare is the main body in the systems of central executive bodies that ensures formation and implementation of state policy in the field of development, production, quality control and sale of medicines, medical immunobiological drugs and medical devices.

In its turn, the Ministry of Social Policy of Ukraine monitors: compliance with the legislation of governing legal relations in the field of social protection of persons with disabilities; production of technical and other means of rehabilitation; compliance of medical devices, technical and other means of rehabilitation with the requirements established by the legislation. The State Architectural and Construction Inspectorate of Ukraine exercises control in the field of housing and communal services to take into account the needs of persons with disabilities during the design, construction, reconstruction and repair of public and civil facilities, landscaping, transport infrastructure, road service with the involvement of representatives of public associations that care for people with disabilities (Law of Ukraine, 2016). 
A passive form of control is monitoring. In the dictionary literature, monitoring is proposed to be understood as a continuous observance of a process in order to identify its compliance with the desired result. Based on this, it becomes obvious that these concepts are close in meaning, however, like supervision, monitoring cannot be equated with control. As rightly noted by O.F. Andriyko, monitoring should be considered as a kind of control, its certain form, which, in comparison with supervision, the consequences of the impact, can be attributed to its passive form. The use of monitoring is associated with the absence of a situation or process in the field of administration, limiting the impact of administrative decisions, legal acts on existing public relations. At the same time, not so much inspection and audit as observation and analysis are used as methods of such activity (Averianov, 2002).

Monitoring as a method of public administration of the right for healthcare for persons with disabilities is carried out in several areas:

1) monitoring the living conditions of persons with disabilities in residential institutions and in case of violations - taking appropriate response measures;

2) weekly monitoring, which data are taken to ensure proper social support for wounded members of the ato;

3) monitoring of measures to ensure unimpeded access for persons with disabilities to residential and public facilities in accordance with the register of such facilities;

4) monitoring of the availability of social and engineering-transport infrastructure facilities;

5) monitoring of the provision of medicines, rehabilitation aids, etc. to persons with disabilities.

An integral part (element) or administration that provides a systematic review of the Constitution, laws of Ukraine, other regulations, discipline and law and lies in identification and prevention of offenses, elimination of their consequences and bringing the perpetrators to justice, without the right to interfere in operational and economic activity of supervised objects, change or cancellation of administrative acts, there is supervision (Bytiak, 2001). The Ministry of Healthcare of Ukraine is the main entity that carries out state supervision over the observance of legislation that guarantees the right for healthcare for persons with disabilities.

Thus, in the process of administrative activity of public administration bodies of the right for healthcare of persons with disabilities at all stages of state provision of this right the various methods of administrative activity are used, among which methods of public administration prevail which have service and administrative nature. At the same time, the methods of regulating their own functioning (methods of the first group) and methods of ensuring the implementation of the goals and functions of public administration of the right for healthcare for persons with disabilities (methods of the second group) are used in the activities of these bodies. The use of the methods of public administration of the right for healthcare of persons with disabilities identified and disclosed by us should be comprehensive and selective, according to specific circumstances, conditions, nature of application of relevant measures, features of referral (medical care, rehabilitation measures, social benefits etc.), the specifics of the implementation of an administrative function. Of course, when choosing and applying a specific method in the system of guaranteeing the right for healthcare for persons with disabilities, it is necessary to take into account the expediency and effectiveness of its application. 


\section{CONCLUSIONS}

Thus, economic methods of public administration of the right of persons with disabilities for healthcare are a set of tools and methods used by authorized subjects of public administration in order to create such economic conditions that contribute to improving the health of persons with disabilities, ensuring accessible and unimpeded environment, improving the professional qualities of medical staff providing medical care to persons with disabilities, the implementation of rehabilitation measures, as well as creating other necessary conditions for integration of persons with disabilities into society.

Economic methods of public administration of the right of persons with disabilities for healthcare are implemented by:

1) Planning of expenditures for ensuring the right for healthcare for persons with disabilities in the state and local budgets.

2) Development, approval of comprehensive programs of social protection and support and rehabilitation of people with disabilities.

3) Development and implementation of rehabilitation measures for persons with disabilities.

4) Development of public-private partnership mechanisms to ensure the right for healthcare of persons with disabilities.

5) Financing from the state and local budgets for development of healthcare institutions that ensure the implementation of the right for healthcare of persons with disabilities, as well as the construction and commissioning of new rehabilitation centres etc.

In our opinion, it is expedient to divide administrative methods of public amnesty of the right for healthcare of persons with disabilities into 4 groups:

1) Methods that ensure the functioning of the relevant state bodies and local governments;

2) Methods that ensure the implementation of the goals and functions of this type of administration;

3) Methods that have a service nature of ensuring the right for healthcare of persons with disabilities (permits, registration, licensing);

4) Methods that have the managerial nature of ensuring the right for healthcare of persons with disabilities (monitoring, accounting, auditing, standardization, control, supervision, administrative liability for violation of the rules that ensure the right for healthcare of persons with disabilities).

\section{REFERENCES}

Atamanchuk, H. V. (2003). Admynystratyvnoe pravo. RAHS.

Averianov, V. B. (2002). Vykonavcha vlada i administratyvne pravo. Kyiv, Vydavnychyi Dim „In-Yure”.

Bandurka, O. M. (1998). Upravlinnia v organakh vnutrishnikh sprav Ukrainy. Kharkiv, Un-t vnutr. sprav.

Bytiak, Iu. P., Harashchuk, V. M., Diachenko, O. V. et al. (2004). Administratyvne pravo Ukrainy. Yurinkom Inter.

Bytiak, Yu. P (2001). Administratyvne pravo Ukrainy. Kharkiv, Pravo.

Bytiak, Yu. P. (2001). Pravovi zasady upravlinskoi polityky na suchasnomu etapi. Konflikty $v$ suspilstvakh, shcho transformuiutsia. Kharkov, Pravo. 
Dorokhova, H. A., Kozyreva, T. Y., Serhyenko, L. A., Shabailov, V. Y. (1988). Upravlenye sotsyalno-kulturnym stroytelstvom. Moscow: Yurydicheskaja literatura.

Ihnatchenko, I. H. (2009). Formy ta metody derzhavnoho upravlinnia kulturoiu v Ukraini. Natsionalna yurydychna akademiia Ukrainy imeni Yaroslava Mudroho.

Kolpakov, V. K. (1999). Administratyvne pravo Ukrainy. K.: Yurinkom Inter.

Kolpakov, V. K., Kuzmenko, O. V. (2003). Administratyvne pravo Ukrainy: Pidruchnyk. K.: Yurinkom Inter, $544 \mathrm{~s}$.

Kozlov, Yu. M. (2003). Admynystratyvnoe pravo. M.: Yuryst.

Krutskykh, V. E. (1999). Entsyklopedycheskyi slovar. Moscow, YNFRA.

Law of Ukraine ( 2018) Pro Derzhavnyi biudzhet Ukrainy na 2019 rik: Zakon Ukrainy vid 23 lystopada 2018 roku, No. 2629-VIII. Vidomosti Verkhovnoi Rady 2018. No. 50. St.400.

Law of Ukraine ( 2019) Pro Derzhavnyi biudzhet Ukrainy na 2020 rik: Zakon Ukrainy vid 14 lystopada 2019 roku, No. 294-IX. Vidomosti Verkhovnoi Rady, 2020. No. 5. St. 31.

Law of Ukraine (1991). Pro osnovy sotsialnoi zakhyshchenosti osib z invalidnistiu $v$ Ukraini: Zakon Ukrainy vid 21 bereznia 1991 roku, No. 875-XII. Vidomosti Verkhovnoi Rady URSR, 1991. No. 21. St. 252.

Law of Ukraine (2007). Pro zatverdzhennia Poriadku nadannia dozvolu na pravo korystuvannia pilhamy $z$ opodatkuvannia dlia pidpryiemstv ta orhanizatsii hromadskykh orhanizatsii invalidiv: zatv. Postanovoiu Kabinetu Ministriv Ukrainy vid 8 serpnia 2007 r. No. 1010. Access on the internet: https://zakon.rada.gov.ua/laws/show/1010-2007-p\#n9

Law of Ukraine (2014). Pro zabezpechennia prav i svobod vnutrishno peremishchenykh osib: Zakon Ukrainy vid 20 zhovtnia 2014 roku № 1706-VII. Vidomosti Verkhovnoi Rady 2015. № 1 . St.1.

Law of Ukraine (2016). Pro zakhody, spriamovani na zabezpechennia doderzhannia prav osib z invalidnistiu: zatv. Ukazom Prezydenta Ukrainy 13 hrudnia 2016 roku, No. 553/2016. Access on the internet: https://zakon3.rada.gov.ua/laws/show/553/2016

Law of Ukraine (2018). Deiaki pytannia vykorystannia koshtiv, peredbachenykh u derzhavnomu biudzheti dlia prydbannia spetsialno obladnanykh avtomobiliv dlia perevezennia osib $z$ invalidnistiu ta ditei z invalidnistiu, yaki maiut porushennia oporno-rukhovoho aparatu: zatv. Postanovoiu Kabinetu Ministriv Ukrainy vid 14 bereznia 2018 r., No.189. Access on the internet: https://zakon5.rada.gov.ua/laws/show/189-2018-p.

Law of Ukraine (2018). Pro derzhavni finansovi harantii medychnoho obsluhovuvannia naselennia. Vidomosti Verkhovnoi Rady, No. 2168-VII. No. 5. St.31.

Lunev, A. E. (1970). Admynystratyvnoe pravo: Uchebnyk dlia vuzov. Moskow.

Ministry of Social Policy of Ukraine (2020). Reabilitatsiia ditei z invalidnistiu vnaslidok dytiachoho tserebralnoho paralichu. Access on the internet: https://www.msp.gov.ua/ content/reabilitaciya-ditey-z-invalidnistyu-vnaslidok-dityachogo-cerebralnogoparalichu.html

Tsvietkov, V. V. (1998). Reformuvannia derzhavnoho upravlinnia v Ukraini: problemy i perspektyvy. Kyiv, Oriiany.

DOI: $10.7862 /$ rz.2021.mmr.09

The text was submitted to the editorial office: May 2021.

The text was accepted for publication: June 2021. 